\title{
Publications Bureau for Central Africa
}

A GRANT has been made from the Colonial Development and Welfare Central African Allocation for the establishment of a joint Publications Bureau to serve Northern Rhodesia and Nyasaland. The new Bureau will act as agent for the production and distribution of school text-books, and books required by the Agricultural, Medical, and other departments, in addition to producing books of more general interest. The production of literature in vernacular languages will be encouraged by competitions, editorial assistance, and the selection of works suitable for translation; the Bureau, while making use of existing publishing and bookselling agencies, will concern itself with arrangements for printing suitable manuscripts, and with the marketing and advertising of publications, and will furnish advice and information to libraries. The proposed Bureau is expected to be of particular value in the work of mass literacy now going on at Ndola and elsewhere. (Other literature bureaux are already active in Northern Nigeria and East Africa.)

\section{Exhibition of African Art in London}

AN exhibition of exceptional and peculiar interest is that of works of art by the pupils of Cyrene school, Southern Rhodesia. The school is a central primary boarding-school for African boys, government-aided but founded and directed by the Anglican Church. The pupils include boys from the Matabele, Mashona, Barozur, and Makalanga tribes of Southern Rhodesia, from Nyasaland, Northern Rhodesia, and Bechuanaland. Their ages range from ro to 20 years. The literary education extends from standard iii to standard vi, but the main emphasis is on crafts-carpentry, wood-work, painting-and courses in building and agriculture form an important part of the syllabus. Every pupil practises an art, though it is claimed that no direct teaching of art is given. The present exhibition consists of drawings in pen and ink, water-colour, and poster colours, carved wood reliefs, statuettes, and carved and decorated wood bowls. The qualities which mainly strike the visitor to the exhibition are the exceptionally delicate and restrained colour, the strong sense of composition and design, and the careful representation of detail which gives the pictures a tapestry-like quality. The way in which the spaces are filled and the material arranged to form a harmonious but in no way formal design is very striking. The pictures also suggest very strongly an extreme sensitivity to and love for the natural environment - the hills, trees, birds, and beasts-and a delight in careful craftsmanship. A certain uniformity in technique and arrangement suggests the influence-probably unconscious-of the teacher. It is to be hoped that some of these young artists will develop a more individual interpretation and technique.

\section{Abstracts of Current Literature}

A REFERENCE was made in an earlier number of this Journal (xviii. 4, p. 24I) to the possibility of the Institute's undertaking the systematic publication of abstracts of current literature on diffetent aspects of African studies. A proposal to establish an abstracting service was included in the memorandum submitted to U.N.E.S.C.O. last autumn (Africa, xviii. 4, p. 308) and the Institute has now received a grant to finance the initial organization and production of a quarterly review devoted to abstracts of current periodical literature in the fields of African anthropology, linguistics, social development, and related topics. Scientific journals of all countries will be covered, and material published during the wat years will be included. Details of scope and organization are now being discussed, and full particulars of the new review, the date of issue, and the price and conditions of sale to members of the Institute and to the general public will be announced in the near future. Those who wish copies to be reserved for them are invited to communicate with the Institute. 